\title{
Biochemical studies on the amylase of Mango Mealybug (Drosicha Stebbingi Green)
}

\author{
Mango unlubitlerinde amilaz üzerinde biyokimyasal çalışmalar \\ (Drosicha Stebbingi Green)
}

\author{
Mubasshir SOHAIL ${ }^{1}$ \\ Muhammad AFZAL ${ }^{1}$
}

\author{
Muhammad Anjum AQUEEL ${ }^{1 *}$ Fayyaz-ur-REHMAN ${ }^{2}$ \\ Abubakar Muhammad RAZA ${ }^{1}$ Muhammad KAMRAN ${ }^{1,3}$ \\ Muhammad Sajjad KHALIL
}

\begin{abstract}
Summary
Mealybug (Drosicha stebbingi Green) is voracious pest of the mango orchards. It causes heavy quality losses and low production of mango fruit (Luhanga \& Gwinner 1993). The research was conducted to control the pest. Isolation, purification and characterization of amylase from mango mealybug were performed. Amylolytic activity was $365 \mathrm{U} / \mathrm{ml}$ in crude homogenate of $D$. stebbingi whereas in acetone precipitation sample activity was $680 \mathrm{U} / \mathrm{ml}$. The optimum $\mathrm{pH}$ and temperature for amylase activity was 6.4 and $50-60^{\circ} \mathrm{C}$, respectively. However, amylase activity was maximum at $3 \%$ of substrate (starch) concentration. Enzymatic activity was inhibited by $\mathrm{Pb}^{2+}, \mathrm{Na}^{1+}, \mathrm{Hg}^{2+}, \mathrm{Ni}^{2+}$ and $\mathrm{Cu}^{2+}$ but $\mathrm{Ca}^{2+}$ enhanced the enzymatic activity. Natural plant extract like Datura (Datura alba), Neem (Azadirachta indica) and citrus (Citrus reticulata) inhibited the amylolytic activity. Molecular weight of amylase was 26 kDa measured by sodiumdodisylsulphate-polyacrylamide gel electrophorasis (SDS-PAGE). Purpose of the research was to evaluate the isolation, purification and biochemical characterization of the digestive enzyme of mango mealybug. The experiment provides better understanding about digestive physiology of mealybug for its efficient control. Biochemical characteristics of digestive amylolytic activity in adults of mango mealybug may open new horizons for its control.
\end{abstract}

Key words: Mango Mealybug, amylase, biochemical characterization

\section{Özet}

Mango unlubiti (Drosicha stebbingi Green) mango bahçelerinde oburca beslenen bir zararlıdır. Mango meyvesinde ağır kalite kaybı ve düşük üretime sebep olmaktadır (Luhanga \& Gwinner 1993). Bu çalışma zararının kontrolü için yapılmıştır. İzolasyon, saflaştırma ve amilaz karakterizasyonu Mango unlubitinden yapılmıştır. Amilolitik aktivite $D$. stebbingi ham homojenat içinde $365 \mathrm{U} / \mathrm{ml}$ iken aseton içinde çökeltme örnek aktivitesi $680 \mathrm{U} / \mathrm{ml}$ olmuştur. Amilaz aktivitesi için optimum pH ve sıcaklık sırasıyla, 6.4 ve $50-60{ }^{\circ} \mathrm{C}$ olmuş, bununla birlikte, amilaz aktivitesi, maksimum alt-tabaka (nişasta) konsantrasyonunun\% 3'ü olmuştur. Enzimatik aktivite Pb2 +, nA1- +, $\mathrm{Hg} 2+, \mathrm{Ni}+2$ ve $\mathrm{Cu}+2$ tarafından önlenmiş, fakat $\mathrm{Ca}+2$ enzimatik aktiviteyi arttırmıştır. Datura (Datura alba), Neem (Azadirachta indica) ve narenciye (Citrus reticulata) gibi doğal bitki ekstraktları amilolitik aktiviteyi engellemiştir. Sodiumdodisylsulphatepoliakrilamid jel elektroforez (SDS-PAGE) ile ölçülen amilaz molekül ağırlığı 26 kDa olmuştur. Araştırmanın amacı izolasyonu, saflaştırmayı ve mango unlubitlerin sindirim enziminin biyokimyasal karakterizasyonunu değerlendirmektir. Bu çalışma unlubitlerin etkin kontrolü için, unlubitlerin sindirim fizyolojisinin daha iyi anlaşılmasını sağlar. Mango unlubitlerin erginlerindeki sindirim amilolitik aktivitesinin biyokimyasal özellikleri zararlının kontrolü için yeni ufuklar açabilir.

Anahtar sözcükler: Mango unlubiti, amilaz, biyokimyasal karakterizasyon

\footnotetext{
${ }^{1}$ Department of Entomology, University College of Agriculture, University of Sargodha, Pakistan

${ }^{2}$ Department of Biochemistry, University of Sargodha, Pakistan

${ }^{3}$ Department of Plant Protection, College of Food and Agricultural Sciences, King Saud University, Riyadh, Kingdom of Saudi Arabia

* Sorumlu yazar (Corresponding author) e-mail: anjum_ento@uos.edu.pk

Alınış (Received): 23.04.2014

Kabul ediliş (Accepted): 15.08.2014
} 


\section{Introduction}

Fruit is an imperative portion in the agriculture sector. Mango (Mangifera Indica L.) is well known for its excellent exotic flavor and usually referred to as the king of fruit (Sivakumar et al. 2011). Over all India is at the top following by China and Thailand. Pakistan is footing at $4^{\text {th }}$ place in mango production by sharing of 1784300 metric ton, which contribute about $13.9 \%$ in the world's total production (MINFAL 2010).

Insect pest of mango attack the mango orchard and consume the important nutrients from the plant body. Damage by insect pests and diseases in mango while mango Mealybug was reported to cause serious damage to various fruit trees, especially mango, in Benin, Ghana and Togo (Agounkè et al. 1988). Even though in Pakistan mango mealybug (Drosicha stebbingi) is one of the serious pests attacking on the fruit trees (Prasad \& Singh 1976; Yousuf 1993). In case of fruit trees, due to the attack of insect pest the yield is reduced severely. Tandon and Verghese (1985) reported that mango mealybug is dangerous for mango fruits. It is not only the pest of mango tree but it also attacks more than 70 other plant (Narula 2003; Tandon \& Lal 1978). Furthermore, majority of the survey showed that mango mealybug is the main pest of mango and caused major losses to the fruit of mango (Bokonon-Ganta et al. 2002).

Mango mealybug have the tendency to infest the diversity of the fruit and ornamental trees in including mango for example, peach (Prunus persica), papaya (Careica papaya), plum ( $P$. domestica) and all citrus cultivars. During peak infestation mango mealybug has been reported in different forest trees and huge amount of crawler and female get approach to tree Dalbergia sisso, Bombyx ceiba, Ficus religiosa, and Populus abla via stem (Khan 2001).

a-Amylase is one of the most important enzyme encountered in microbes, higher and lower plants, and animals (Kadziola et al. 1993). Amylase is one of the key enzymes involved in digestion and carbohydrate metabolism in insects. These enzymes different origins including bacteria, mammals, nematodes and insects have been purified and their physical and chemical properties characterized (Mohammed 2004; Oliveira-Neto et al. 2003; Rao et al. 2005; Zoltowska 2001).

This study aims to undertake the purification and biochemical characterization of a-amylase sourced from the digestive tract of Drosicha stebbingi (Green) the mango mealybug, in order to gain a better understanding of its digestive physiology and to investigate a new potential good source of IPM for the mango mealybug. It will also help in reducing the incremental used of conventional insecticides.

\section{Materials and Methods}

\section{Insect collection}

Mango mealybugs were collected from different sources like stem, twigs and branches of mango tree and as well as from other ornamental trees at University College of Agriculture, University of Sargodha. Collection was done during the month of February to April in 2011 at a variety of temperatures between $25^{\circ} \mathrm{C}$ to $40^{\circ} \mathrm{C}$ and in $55 \%-70 \%$ humidity. These Mango mealybugs were stored at $4^{\circ} \mathrm{C}$, for further experiments. Insect were identified as Drosicha stebbingi (Homoptera: Margarodidae).

\section{Preparation of crude enzyme}

$50 \mathrm{~g}$ of 33 individuals of mealybug were first washed in order to remove the mealy powder from the insect body and dried by spreading them on layer of filter paper. Mealybugs were homogenized by using mortar and pestle with regular addition of the buffer of $0.2 \mathrm{M}$ sodium- phosphate $(\mathrm{pH} 7.0)$ and overnight at room temperature (Rehman et al. 2009). Homogenized mixture was centrifuged in centrifuge machine at $10,000 \mathrm{rpm}$ for 15 minutes. The pellets were air dried and dissolved in $10 \mathrm{ml}$ of $0.1 \mathrm{M}$ sodium phosphate of $(\mathrm{pH} 7.0)$ This was also stored at low temperature at $4^{\circ} \mathrm{C}$. Then $50 \mathrm{ml}$ of filtered homogenate was added 
to $200 \mathrm{ml}$ of ice-cold acetone at $4^{\circ} \mathrm{C}$ overnight to precipitation of protein enzyme. Chilled acetone was used during protein precipitation so that the heat released in this process would not denature the enzymes. Next day mixture was centrifuged at $10,000 \mathrm{rpm}$ for 15 minutes. The pellets were air dried and dissolved in minimum quantity of $0.2 \mathrm{M}$ sodium-phosphate buffer of $\mathrm{pH} 7$. The sample was stored at $4^{\circ} \mathrm{C}$ and used as a crude enzyme source.

\section{Screening of Enzyme Activity}

To screen the amylase activity in the crude protein extract a modification of Congo Red Plate Assay Rehman et al (2009) was used. Amylase activity was confirmed by observing the cleared zone formation around the sample well against a red-stained background on agar plates. Pre-sterilized plates were used for substrate agar plate assay. Agar gels were prepared by mixing $5 \mathrm{ml}$ of $3 \%$ agar and $5 \mathrm{ml}$ of $3 \%$ starch for amylase activity. Then $5 \mathrm{ml}$ of $0.1 \mathrm{M}$ sodium phosphate buffer $(\mathrm{pH} \mathrm{6.0)}$ ) was mixed with 10 $\mathrm{ml}$ substrate - agar mixture. About $15 \mathrm{ml}$ of agar gel solution was poured in petri-plates and gel was left to solidify. After the solidification, wells were made in the center of the agar plate and loaded the enzyme with the volume $100 \mu \mathrm{l}$. Substrate - agar plates along with enzyme were incubated over night at $37^{\circ} \mathrm{C}$. Next day plates were stained with $0.1 \%$ Congo red for $15 \mathrm{~min}$ at room temperature, followed by destaining with Sodium Chloride $(1.0 \mathrm{M})$ for 30 minute with gentle shaking.

\section{Total Protein Estimation}

Total protein in the sample was measured using the dye binding method of Bradford (1976) using bovine serum albumin as a substrate using modified method of (Rehman et al. 2009). To prepare dye binding reagent $100 \mathrm{mg}$ Coomassie Brilliant Blue G250 (shandon) was dissolved in $50 \mathrm{ml}$ of $95 \%$ ethanol following by mixing it with $100 \mathrm{ml}$ of orthophosphoric acid. The solution was diluted to 1.0 liter by adding distilled water and filtered the dye twice to remove undissolved particles. For protein estimation $2.5 \mathrm{ml}$ of dye binding reagent was added to $100 \mu \mathrm{l}$ of protein sample and absorbance was measured at $595 \mathrm{~nm}$ against reagent black after 5 minutes. The reagent blank was prepared by dissolving $100 \mu \mathrm{l}$ of distilled water and $2.5 \mathrm{ml}$ of dye binding reagent. Then the concentration of protein was calculated by plotting the standard curve.

\section{Measurement of Enzyme Activities}

Enzyme assay was performed by measuring the amount of reducing sugar by using modified 2.2dinitrosalicylic acid method (DNS) taking the glucose as standard (Rehman et al. 2009). DNS reagent was prepared by using $10 \mathrm{~g}$ of 2.2 - dinitro salicylic acid method (DNS) dissolved in $200 \mathrm{ml} 2.0 \mathrm{M}$ sodium hydroxide $(\mathrm{NaOH})$ followed by addition of $500 \mathrm{ml}$ of $60 \%$ sodium-potassium tatrate. Both solutions were mixed, made the final volume of $1000 \mathrm{ml}$ and filtered the solution. To estimate reducing sugars produced by enzyme reaction, concentration of the released glucose was measured from a standard glucose curve enzyme activity (U/ml) was determined (Rehman et al. 2009).

\section{Amylase Assay}

Reaction mixture was made by adding the $100 \mu \mathrm{l}$ of the crude enzyme sample solution to $0.5 \mathrm{ml}$ of starch $(3 \% \mathrm{w} / \mathrm{v})$ and $0.5 \mathrm{ml}$ of $0.1 \mathrm{M}$ Phosphate buffer $(\mathrm{pH} 6.5)$ mixture. The mixture was incubated overnight a $4{ }^{\circ} \mathrm{C}$. After incubation, $3 \mathrm{ml}$ of DNS reagent was added to the enzyme mixture and incubated in boiling water bath for $15 \mathrm{~min}$. Absorbance was measured at $540 \mathrm{~nm}$ against reagent blank prepared by adding $100 \mu \mathrm{l}$ distilled water, $0.5 \mathrm{ml}$ of $3 \%$ starch and $0.5 \mathrm{ml}$ of phosphate buffer of $\mathrm{pH} 6.0$.

\section{Characterization of Enzyme Activity}

\section{pH Profile}

To determine the $\mathrm{pH}$ profile of amylase and cellulase activity, the enzyme assay was carried out using buffers of different $\mathrm{pH}$. Citrate buffer from $\mathrm{pH}$ (3.0-5.6) and phosphate buffer from $\mathrm{pH}(5.8-\mathrm{pH} 8.0)$ 
were used. The assay was performed by adding $100 \mu$ enzyme and mixed in $500 \mu \mathrm{l} 3 \%$ starch and 500 $\mu \mathrm{l}$ of buffer $\mathrm{pH}(3.0-5.6)$ and $\mathrm{pH}(5.8-8.0)$ for the amylase activity. Cellulase activity assay was carried out by taking $100 \mu \mathrm{l}$ enzyme was mixed in $500 \mu \mathrm{l} 2 \% \mathrm{CMC}$ and $500 \mu \mathrm{l}$ of buffer $\mathrm{pH} 3-5.6$ and $\mathrm{pH}$ 5.8-8.

\section{Temperature Profile}

In order to determine the optimal assay temperature, the reducing sugars released from the starch was assayed at temperature $4^{\circ} \mathrm{C}$ to $80^{\circ} \mathrm{C}$ by DNS method as described above. The reaction mixture was prepared by adding $100 \mu \mathrm{l}$ enzyme sample in $0.5 \mathrm{ml} 3 \%$ starch and $0.5 \mathrm{ml}$ sodium phosphate buffer $\mathrm{pH}$ 6.0 for the amylase activity but the cellulase activity required $100 \mu \mathrm{l}$ enzyme sample in $0.5 \mathrm{ml} 2 \% \mathrm{CMC}$ and $0.5 \mathrm{ml}$ sodium phosphate buffer $\mathrm{pH} 5.8$. The absorbance was taken on $540 \mathrm{~nm}$ against the reagent blank.

\section{Effect of Substrate Concentration}

For amylolytic activity, effect of substrate concentration was studied using different concentrations of starch ranging from $1.0 \%-5.5 \%$ in the assay mixture $(100 \mu \mathrm{l}$ of enzyme sample was mixed with 1.0 $\%$ to $5.5 \%$ starch and $500 \mu \mathrm{l}$ of buffer $(\mathrm{pH} 5.8)$. Than reaction mixture was incubated at $50{ }^{\circ} \mathrm{C}$. For the cellulytic activity, we studied the effect of different substrate concentration of CMC ranging from $0.5 \%$ $3.5 \%$ with the reaction mixture $(100 \mu \mathrm{l}$ of enzyme sample was mixed with $0.5 \%$ to $3.5 \% \mathrm{CMC}$ and 500 $\mu \mathrm{l}$ of buffer $\mathrm{pH}$ 5.8). Than reaction mixture was incubated at $50^{\circ} \mathrm{C}$.

\section{Effect of Metal Ions on Enzyme Activity}

Different metal ions were used to study their effect on amylase enzyme. Effect of metal ions on digestive enzyme (amylase) were studied using different concentrations mercury $\left(\mathrm{Hg}^{2+}\right)$, calcium $\left(\mathrm{Ca}^{2+}\right)$, strontium $\left(\mathrm{Sr}^{2+}\right)$, nickel $\left(\mathrm{Ni}^{2+}\right)$, cobalt $\left(\mathrm{Co}^{2+}\right)$, copper $\left(\mathrm{Cu}^{2+}\right)$, lead $\left(\mathrm{Pb}^{2+}\right)$, sodium $\left(\mathrm{Na}^{+}\right)$and potassium $\left(\mathrm{K}^{+}\right)$ were used in reaction mixture.

In reaction mixture $100 \mu \mathrm{l}$ of enzyme was mixed with $0,100,200,300,400$ and $500 \mathrm{ppm}$ concentration of metal ions from $\mathrm{HgCl}_{2}, \mathrm{CaCl}_{2}, \mathrm{SrCl}_{2}, \mathrm{NiCl}_{2} \cdot 6 \mathrm{H}_{2} \mathrm{O}, \mathrm{CoCl}_{2} \cdot 6 \mathrm{H}_{2} \mathrm{O}, \mathrm{Pb}\left(\mathrm{NO}_{3}\right)_{2}, \mathrm{CuCl}_{2} \cdot 2 \mathrm{H}_{2} \mathrm{O}$, $\mathrm{NaCl}$, and $\mathrm{KCl}$. Mixed gently, add $500 \mu \mathrm{l}$ of buffer of $\mathrm{pH} 6.0$ and $500 \mu \mathrm{l}$ of substrate $(3 \%$ starch for amylase activity), Incubated it overnight at $50{ }^{\circ} \mathrm{C}$ temperature. After this $3 \mathrm{ml}$ of DNS was added in each reaction mixture. Boiled the reaction mixtures in pre-heated boiling water and filtered it. The reading of reaction mixtures were taken at $540 \mathrm{~nm}$. DNS was taken as blank and control reaction mixture includes $100 \mu \mathrm{l}$ of enzyme, $500 \mu \mathrm{l}$ of substrate (3\% starch for amylase activity) and $500 \mu \mathrm{l}$ of buffer (pH 6.0).

\section{Effect of Natural Inhibitors}

Inhibition of enzyme activities of Drosicha stebbingi other than with metal ions can also be take place with natural inhibitors like Datura (Datura alba), Neem (Azadirachta indica) and citrus (Citrus reticulata) plant extracts.

\section{Preparation of Extract from Plant Origin}

Fresh leaves of Datura, Neem and peel of citrus fruit were collected from the different areas in University College of Agriculture, University of Sargodha, Sargodha, Punjab, Pakistan in the July 2013. By distilled water peel and leaves were properly washed and then air dried to original weight. Then weighed quantities of leaves and peel of citrus were homogenized in buffer of sodium phosphate $(\mathrm{pH}$ 7.0). $50 \mathrm{~g}$ of fresh leaves of Datura, Neem and peel of citrus were taken, properly washed then air dried and weighed. Air dried leaves of Datura, Neem were grounded into fine powder, then 20 grams of powdered leaves homogenized in $100 \mathrm{ml}$ of methanol respectively with gentle shaking for $72 \mathrm{hrs}$. After 72 hrs filter the mixture and allowed it to dry at $40{ }^{\circ} \mathrm{C} .100 \mathrm{mg}$ of filtered dried leaves powder dissolved in 10 $\mathrm{ml}$ of distilled water and make the concentrations. To determine the effect of natural substrates, reaction was carried out containing the $100 \mu \mathrm{l}$ of enzyme with varying concentrations of natural plant extracts. 


\section{Purification of Enzyme}

Protein purification amylase activity was purified using the chromatographic techniques. The crude enzyme sample was fractionated at $4^{\circ} \mathrm{C}$ using the swollen sephadex G-75 suspension, packed in a column $(1.6 \times 16 \mathrm{~cm})$. The amylase activity and protein concentration were determined by enzyme assay in collected fractions. Active fractions having amylase activity were pooled and subjected to ion exchange chromatography for further purification. Active fractions were loaded into ion exchange column $(0.8 \times 15$ $\mathrm{cm}$ ) packed with the DEAE-sephadex gel and equilibrated with Tris-HCl buffer. Sample was loaded and the bound proteins were eluted by a linear gradient of $0-0.5 \mathrm{M} \mathrm{NaCl}$ in Tris- $\mathrm{HCl}$ buffer $(\mathrm{pH} 8.5)$. A total of 55 fractions $(2 \mathrm{ml}$ each) were collected. Protein concentration and enzyme activity were determined in each fraction by dye binding assay (Bradford, 1976) and DNS method. For estimation of protein $2 \mathrm{ml}$ of bradford reagent was added to $0.5 \mathrm{ml}$ of each fraction, absorbance was noted at $595 \mathrm{~nm}$ and concentration was determined by using the BSA standard curve. Active pooled fractions were stored at $4^{\circ} \mathrm{C}$.

\section{SDS-page}

SDS-Polyacrylamide gel electrophoresis (PAGE) was performed under non-denaturing conditions (Sami \& Akhtar 1990). Active fractions from ion exchange chromatography were subjected to electrophoresis. After electrophoresis gel was cut in two strips vertically. One strip was placed onto substrate agar plate to locate the position of amylase activity on gel. Substrate agar gel plate was prepared using the $3 \%$ agar and $2 \%$ starch, mixed with buffer of $\mathrm{pH} 4.8$. After incubation for $3 \mathrm{~h}$ at $40^{\circ} \mathrm{C}$, gel strip was removed followed by staining and detaining of substrate agar plate with $0.1 \%$ congo red dye and $0.5 \mathrm{M}$ sodium chloride respectively.

\section{Results}

\section{Screening for Amylase Activity}

Enzyme sample from Drosicha stebbingi was added in the starch agar plates and incubated for 24 hours. Staining and de-staining of agar plates with potassium iodide solution. Amylolytic activity was observed. From the assay it is conformed that amylase enzyme is present in the crude protein extracted by observing the white zone development around the sample well against a black stained background on assay plates (Fig. 1).

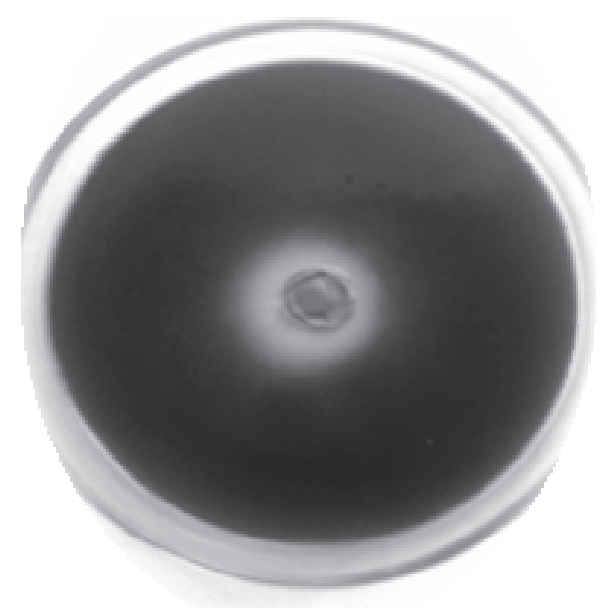

Figure 1. Agar plate assay of Drosicha stebbingi indication the existence of amylolytic activity by formation of white zone in centre of plate at $\mathrm{pH} 5.8$. 


\section{Total Protein Estimation}

The total crude protein from the D.stebbingi was estimated before the acetone precipitation and after precipitation with the ice cold acetone. The standard curve of protein plotted by using the BSA as standard. The protein present in the sample of mango mealybug before acetone precipitation was about $360 \mu \mathrm{g} / \mathrm{ml}$ while in the case of acetone precipitated sample total protein was estimated about $720 \mu \mathrm{g} / \mathrm{ml}$ from the standard protein curve.

\section{Determination of Amylolytic Activity (Enzyme Assay)}

Amylolytic activity from the protein sample of D.stebbingi was measured by using the standard curve of glucose. Amylolytic activity was $365 \mathrm{U} / \mathrm{ml}$ in D.stebbingi crude homogenate whereas in acetone precipitation sample activity was $680 \mathrm{U} / \mathrm{ml}$.

\section{Characterization of enzyme}

\section{Effect of substrate concentration}

Figure 2 showed the different levels of amylase activity at different substrate concentration. Firstly activity of amylase enzyme increases at substrate concentration from $1 \%$ to $3 \%$. Maximum enzyme activity was at $3 \%$ to $3.5 \%$ starch concentration. Then after that amylase activity started to decrease from $3.5 \%$ to $5.5 \%$.

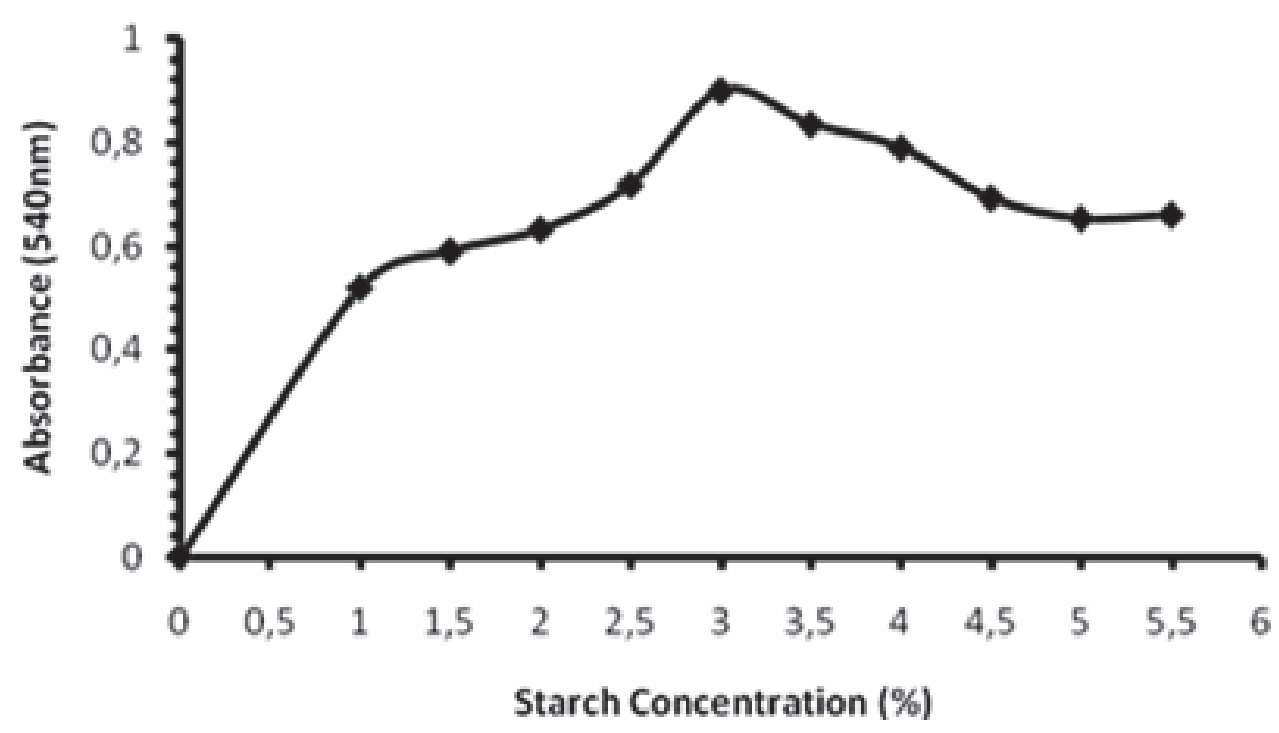

Figure 2. Effect of substrate concentration on Amylase activity of enzyme of Drosicha stebbingi.

\section{Effect of pH profile on amylase activity}

$\mathrm{pH}$ profile for the amylase activity was evaluated for getting the optimum activity of enzyme. In the case of amylase enzyme of the $D$.stebbingi, activity was observed to maximum at $6.4 \mathrm{pH}$. Minimum value of enzyme activity showed that highly acidic medium is not best suited for the amylase activity (Fig. 3). 


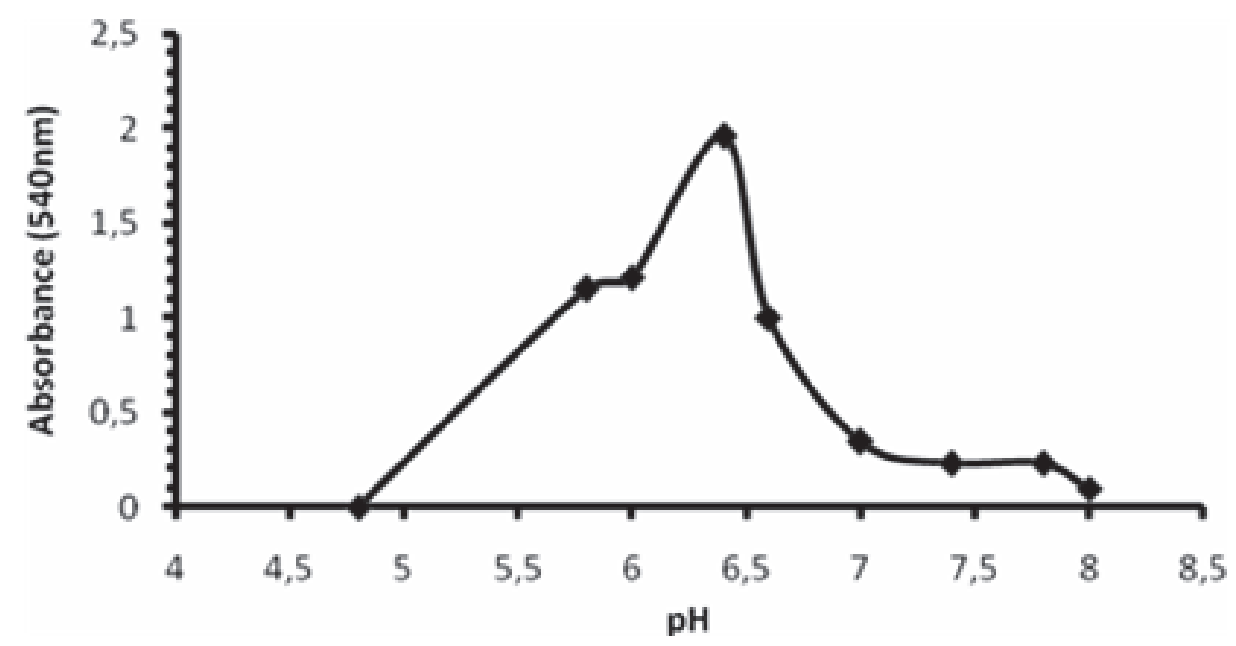

Figure 3. pH profile of Amylase activity of enzyme sample of Drosicha stebbingi.

\section{Temperature Assay}

\section{Effect of Temperature on Amylase activity}

To investigate the change in activity of amylase enzyme was studied by keeping enzyme amount constant at different levels of temperature. Results indicated that at temperature $4^{\circ} \mathrm{C}$ to $30^{\circ} \mathrm{C}$ amylase activity was very near to the ground but peak and maximum activity of enzyme was observed at temperature $50^{\circ} \mathrm{C}$ and $60^{\circ} \mathrm{C}$ but onward there was a stepping decline in amylase activity till the temperature up to $90^{\circ} \mathrm{C}$ (Fig. 4).

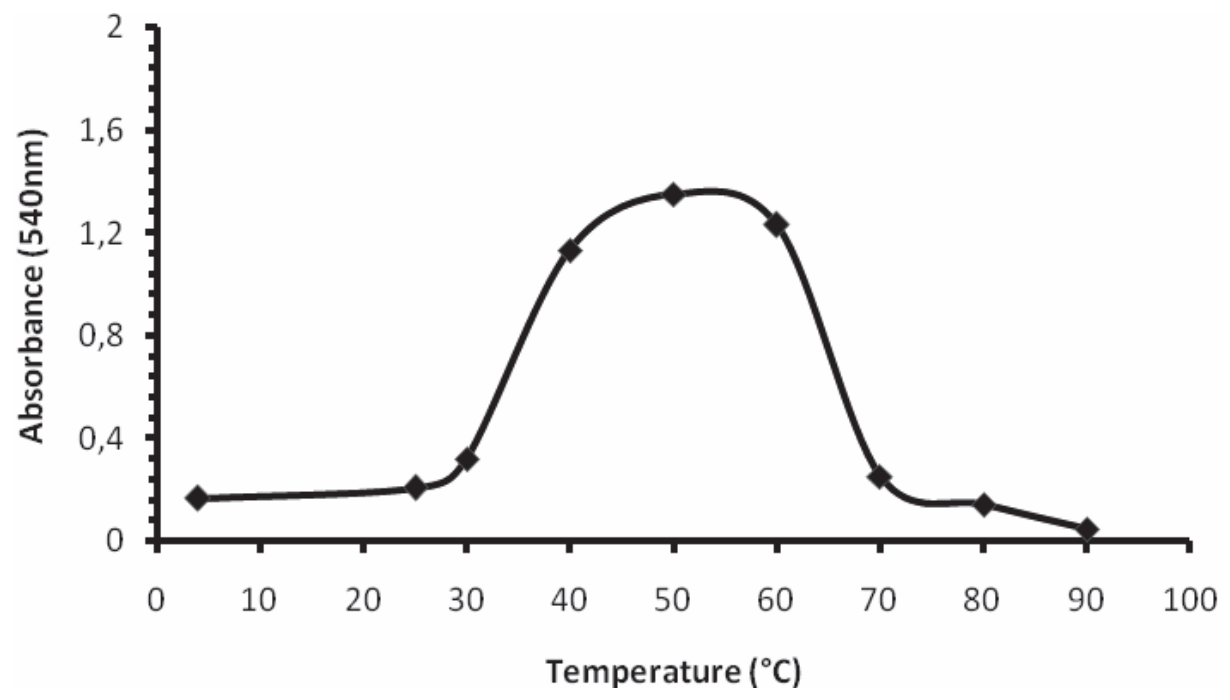

Figure 4. Temperature profile of Amylase activity of enzyme sample of Drosicha stebbingi. 


\section{Effect of metals ions}

\section{Effect of lead lons}

To investigate the change in activity of amylase enzyme was studied by keeping enzyme amount constant at different lead ions concentration. Results indicated that at $400 \mathrm{ppm}$ to $500 \mathrm{ppm}$ amylase activity was very near to the ground but peak and maximum activity of enzyme was observed at $0 \mathrm{ppm}$ but there was a steeping decline in amylase activity from zero to onward till 500 ppm (Fig. 5).

\section{Effect of Cobalt lons}

Graph showed the different levels of amylase activity at different ions concentration of cobalt. There was no significance change in the activity of amylase enzyme after zero ppm of cobalt ions. Graph illustrated that amylase enzyme activity was shown to be the constant at different ppm solution of the cobalt ions (Fig. 5).

\section{Effect of Mercury lons}

Graph showed the different levels of amylase activity at different mercury ions concentration. Inhibition of amylase enzyme is high at different mercury ions concentration and activity remains constant from $300 \mathrm{ppm}$ concentration to onward. Graph illustrated that maximum enzyme activity was at zero ppm of the metal (Fig. 5).

\section{Effect of Calcium lons}

By varying the concentration of calcium ions activity of the amylase enzyme was observed. There was increase in amylase activity by increasing in calcium ion concentration but the maximum activity was observed at 500 ppm concentration of calcium ions (Fig. 5).

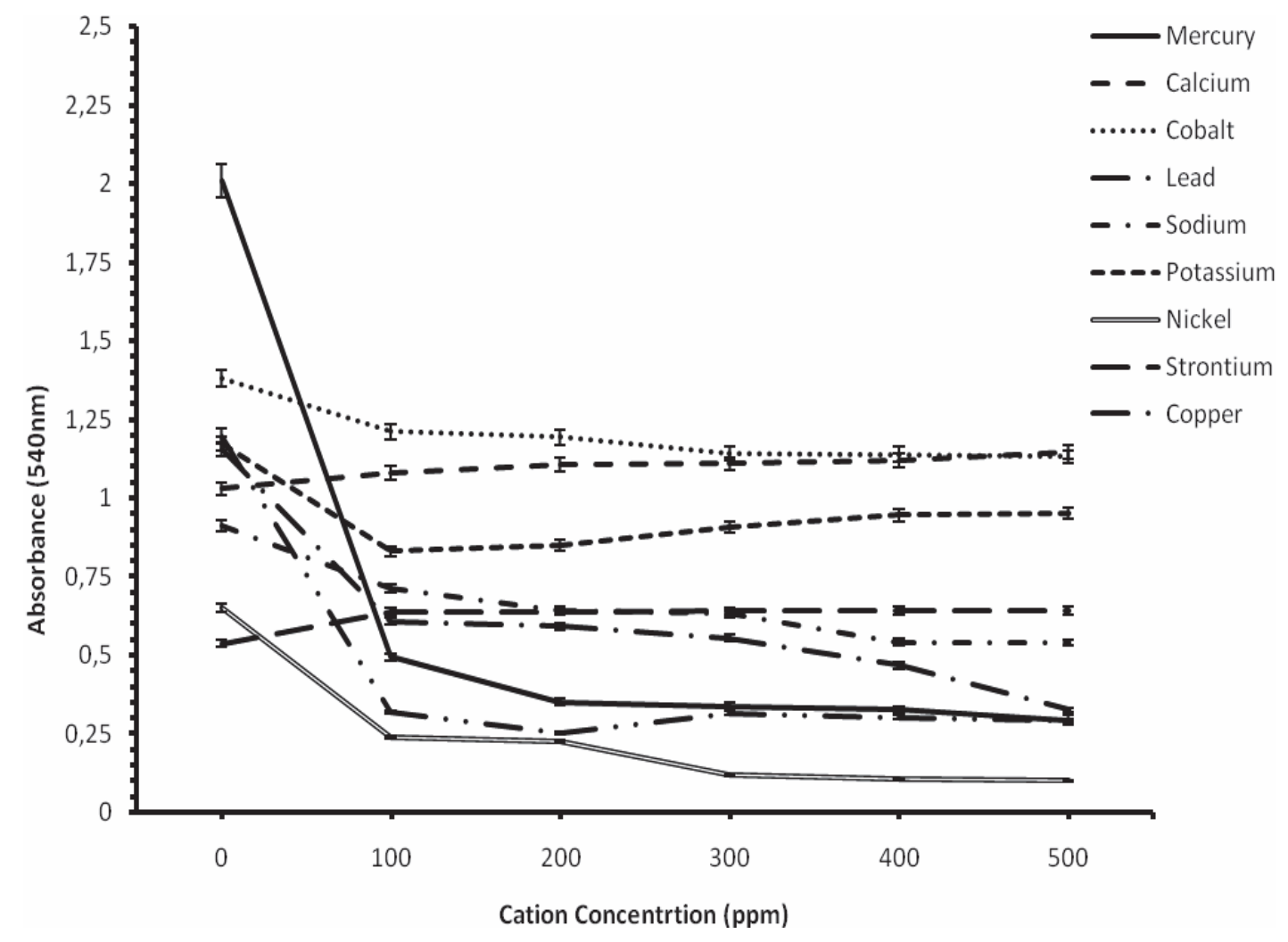

Figure 5. Effect of some cations on Amylase activity of enzyme sample of Drosicha stebbingi. 


\section{Effect of Sodium lons}

Graph showed the different levels of amylase activity at different concentration of sodium ions. Activity of amylase enzyme has the peak values at zero ppm of sodium ions. Graph illustrated that amylase enzyme activity was decreased by increase in ppm solution of the sodium ions (Fig. 5).

\section{Effect of Potassium lons}

Cellulase study of the D.stebbingi indicated that enzyme activity have the variation with respect to the different levels of potassium ion. Analysis showed that there was a significant relationship between cellulase activity and metal ion concentration, while making elevation and depression by curve. Enzyme activity indicated the peek value at 200 to 300 ppm (Fig. 5).

\section{Effect of Nickel lons}

The effect of nickel ion was observed by different concentration of nickel chloride from 0 to 500 ppm. Impulsive decrease occurred in the amylase activity just after the $0 \mathrm{ppm}$. At the end from 300 to $500 \mathrm{ppm}$ the activity of enzyme become the constant (Fig. 5).

\section{Effect of Strontium (Sr) lons}

The effect of $\mathrm{Sr}$ ions to amylase enzyme activity of the D.stebbingi were studied. Curve showed the maximum inhibition of cellulase at $0 \mathrm{ppm}$ of $\mathrm{Sr}$ ions. After that surprising increase occurred in cellulase activity at $100 \mathrm{ppm}$ to $200 \mathrm{ppm}$. After that activity little bit increased but remained constant from 300 to 500 ppm (Fig. 5).

\section{Effect of Copper lons}

Effect of copper ion on the amylase activity of D.stebbingi was studied. Different concentrations of copper were subjected to the reaction mixture. Maximum activity of the amylase enzyme was at $0 \mathrm{ppm}$ of copper concentration. After 0 ppm drastic decrease in enzyme activity occurred from $100 \mathrm{ppm}$ to onward but amylase activity remained constant from 300 ppm to 500 ppm of copper ions (Fig. 5).

\section{Effect of natural plant extracts}

\section{Effect of datura extract}

Effect of Datura extract on the amylase activity of D.stebbingi was studied. Different concentration of extract was subjected to the reaction mixture. Maximum activity of the amylase enzyme was at $0 \mathrm{ppm}$ of Datura extract. After 0 ppm drastic decrease in enzyme activity occurred from 100 ppm to onward (Fig. 6).

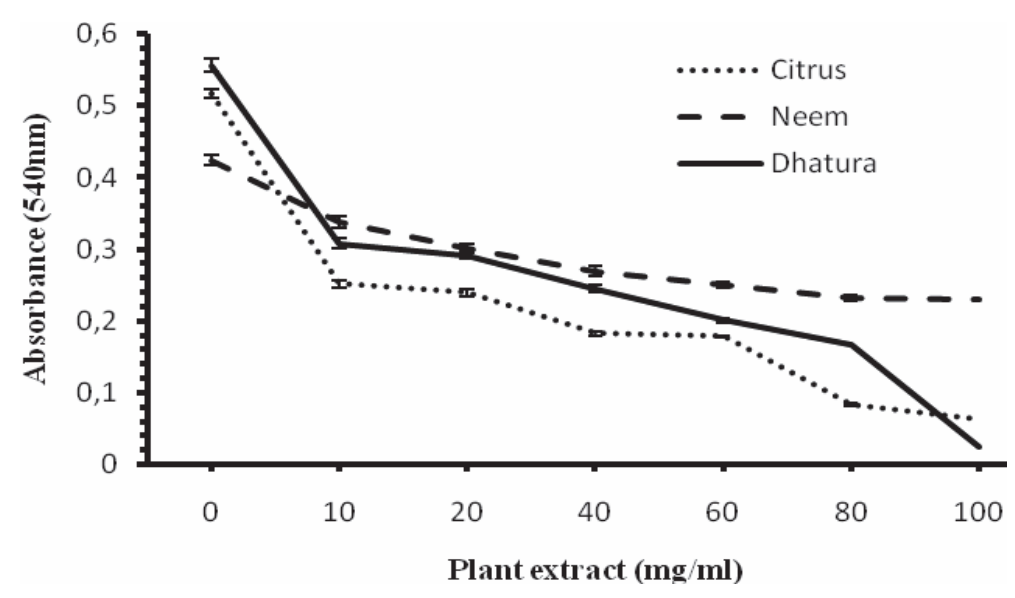

Figure 6. Effect of some plant extracts on Amylase activity of enzyme sample of Drosicha stebbingi. 


\section{Effect of Neem Extract}

Effect of Neem extract on the amylase activity of $D$. stebbingi was studied. Different concentration of extract from $0 \mathrm{mg} / \mathrm{ml}$ to $100 \mathrm{mg} / \mathrm{ml}$ was subjected to the reaction mixture. Amylase activity has variation with respect to different concentration of Neem extract. Amylase activity was decreased first as increase in Neem extract concentration from $0 \mathrm{mg} / \mathrm{ml}-20 \mathrm{mg} / \mathrm{ml}$. After it little bit increase occurred and then enzyme activity started to decline with minimum enzyme activity at $100 \mathrm{mg} / \mathrm{ml}$ (Fig. 6).

\section{Effect of Citrus Peel Extract}

Effect of the citrus peel extract was observed with varying the concentration from $0 \mathrm{mg} / \mathrm{ml}-100$ $\mathrm{mg} / \mathrm{ml}$. Results indicated that enzyme activity have the variation with respect to the different concentration of citrus peel extract. The decrease in amylase activity was observed as increase in extract concentration. Maximum enzyme activity was observed at $0 \mathrm{mg} / \mathrm{ml}$ while the minimum amylase activity was at $80-100$ $\mathrm{mg} / \mathrm{ml}$ (Fig. 6).

\section{Purification of Enzyme}

\section{Gel Filtration Chromatography}

The acetone precipitated crude concentrated enzyme sample was subjected on sephadex G-100 column for the Gel-filtration chromatography. Fractions were evaluated by $0.2 \mathrm{M}$ phosphate buffer of $\mathrm{pH}$ 7.0. The enzyme activity and protein concentration were determined in each fraction.

\section{Gel filtration Chromatography for the amylase}

All samples were evaluated for the protein concentration and amylase activity. Peak fractions having the maximum protein concentration were lying from 10-25 with the climax absorbance $2.28 \mathrm{~nm}$ at 21 no fraction. But the highest amylase activities were at two places within the graph at 14, 15, 16, 17, 18 and $21,22,23,24,25 \& 26$. These samples were collected for the further purification (Fig. 7).

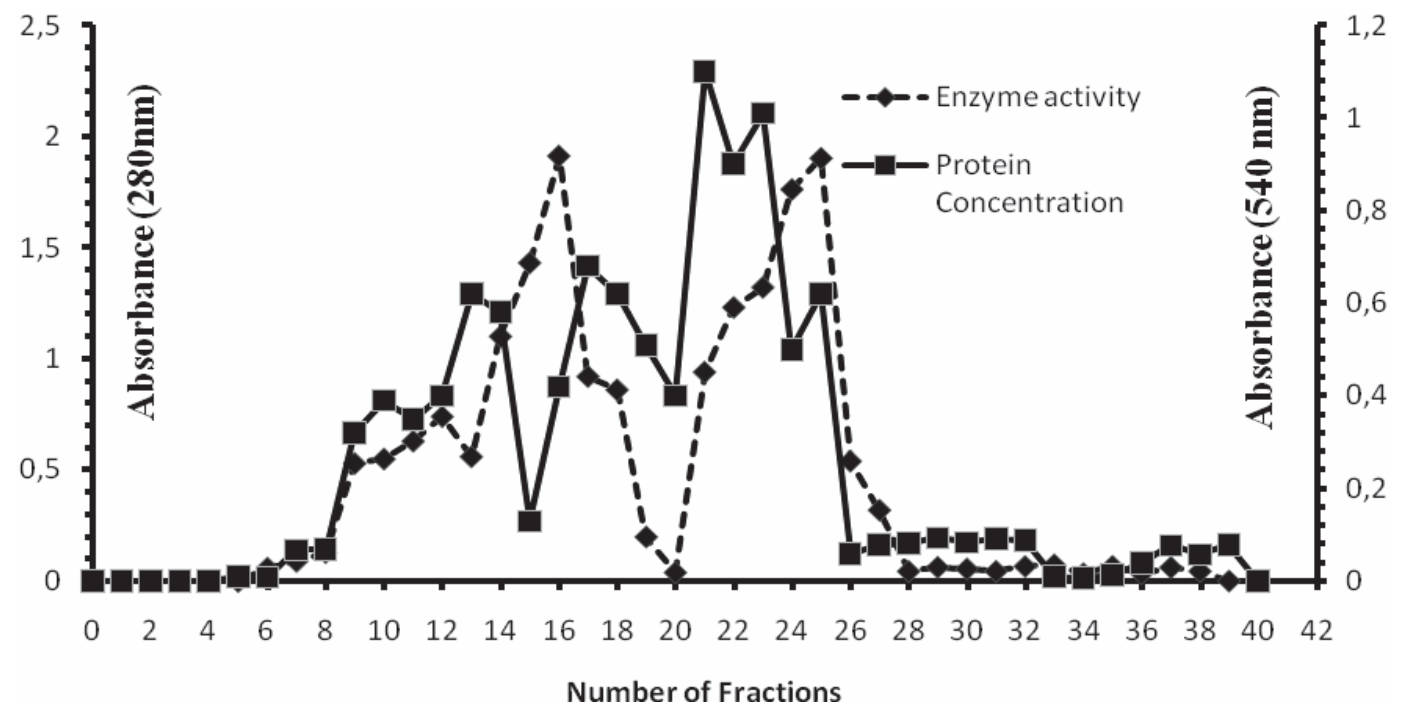

Figure 7. Purification of enzyme activity of Drosicha stebbingi by Gel Filtration Chromatography. And Amylase activity in Gel Filtration fractions. 


\section{lon-Exchange Chromatography}

The partially purified sample was fractioned on a DEAE-sepharose chromatographic column. Active pooled fractions from the gel filtration were loaded. Elution was done with increasing gradient of $\mathrm{NaCl}(0.05-0.5 \mathrm{M})$ in $0.05 \mathrm{M}$ Tris- $\mathrm{Cl}$ buffer $(\mathrm{pH} 8.0)$. The fractions were analyzed for protein concentration and enzyme activity. Protein concentration was high in the following fractions; 18, 19, 20, 25, 26, 43, 44, 45,46 and 48 .

\section{Ion-Exchange Chromatography for Amylase}

Ion-Exchange fractions were analyzed for the amylolytic activity. Maximum values were at the fractions no 25, 26, 27, 40, 41 and 42. Active fractions were pooled and SDS-PAGE was done to calculate the molecular weight of the protein (Fig. 8).

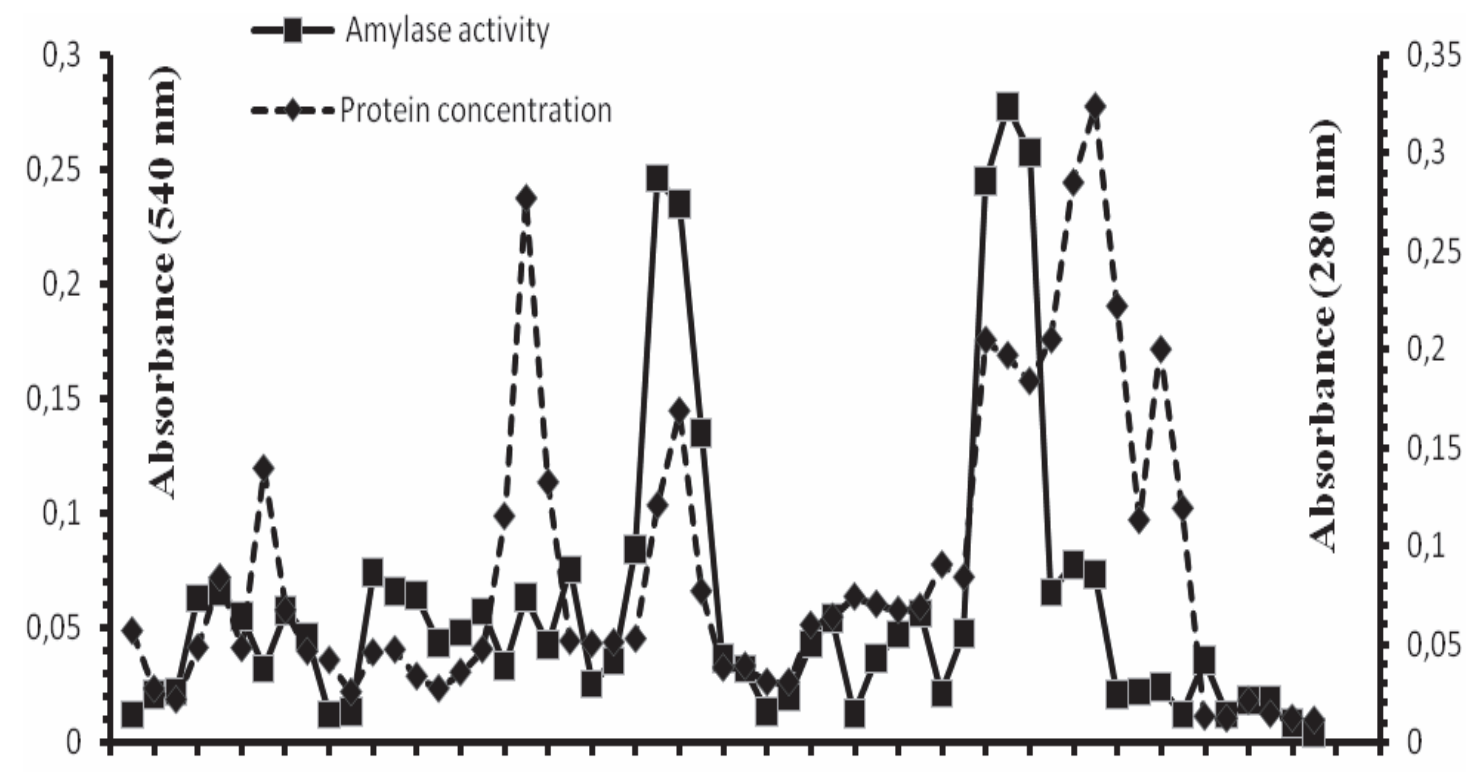

022466810121416182022242628303234363840424446485052545658

N umber of Fractions

Figure 8. Ion Exchange Chromatography through a DEAE-Sephadex column, Elution was done at $0.5 \mathrm{ml} / \mathrm{min}$ with linear salt gradient. And Amylase activity in lon-Exchange fractions.

\section{Molecular Weigh Determination}

By the SDS-PAGE molecular weight of amylase for mealybug was determined that is $24 \mathrm{KDa}$ (Fig. 9). 


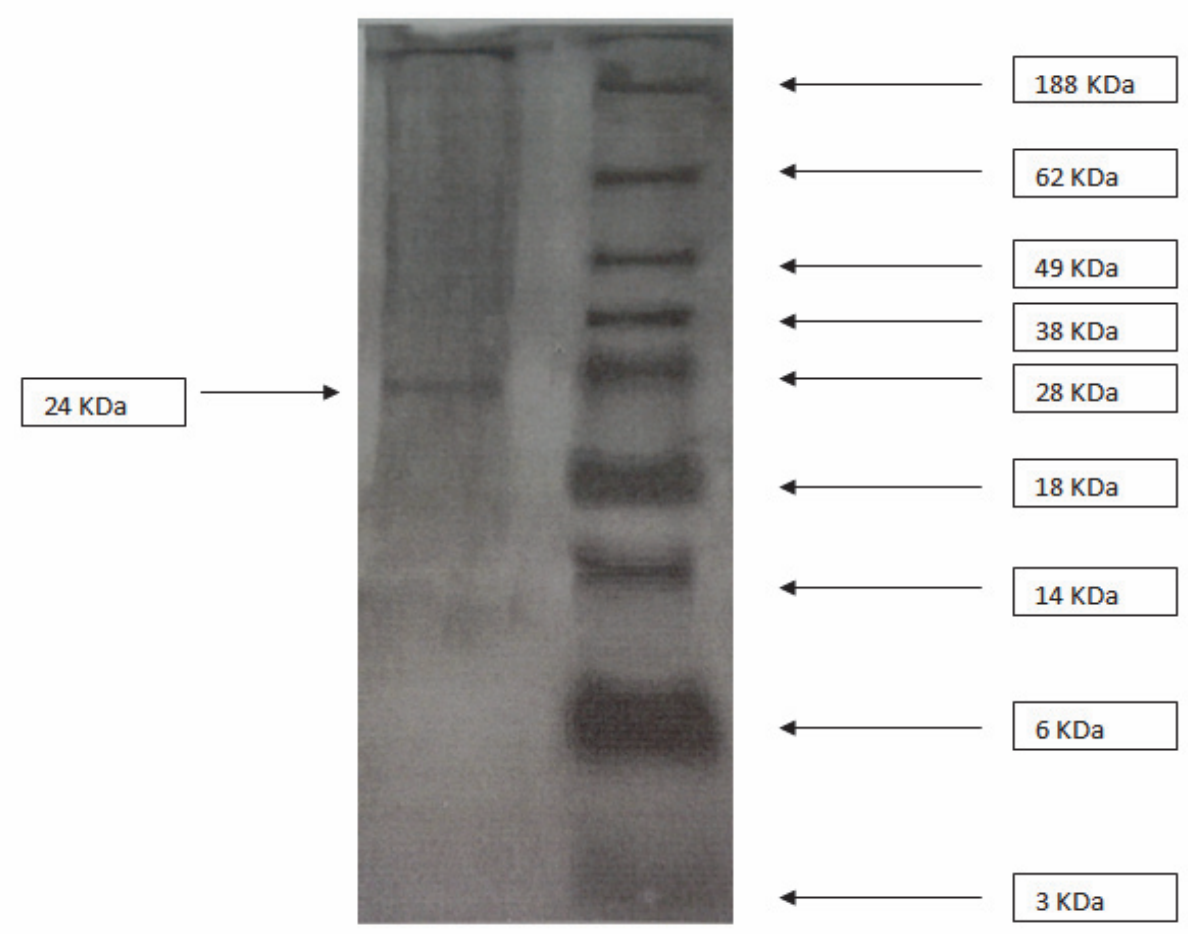

Figure 9. Amylase activities on SDS-PAGE.

\section{Discussion}

Mango mealybug (Drosicha stebbingi) is a voracious pest of mango, which was chosen for the biochemical studies of digestive enzymes. Our study consisted on the isolation, purification and characterization of the amylases of the mealybug. From different localities of Sargodha district the samples were collected and stored at $4{ }^{\circ} \mathrm{C}$ for the further processing. After the identification of the specimens, samples were subjected for the screening of amylolytic activity. For the amylase an assay was preformed with the crud sample, precipitated by the acetone. After the staining with $\mathrm{KI}$ solution, the activity was observed by the presence of white zone development around the sample well against a black stained background (Fig. 9).

Amylase may either be produced by the mango mealybug as genes of the amylase enzyme are also possessed by other invertebrates like some insect, mollusks and nematodes (Watanabe \& Tokudat 2001). P.citri also posses the endoglucanase activity (Rehman et al. 2009). Mehrabadi \& Ali (2009) screened alpha-amylase activity from the Eurygaster moura larvae.

It has been evaluated that in the case of amylase, maximum activity was observed at $3 \%$ of starch as also described that optimal amylolytic activity was observed at $2 \%$ of starch (Shalom \& Pratten 2008).

Amylase results of previously studies showed that E.Maura has amylase peak activity between 6.57 (Mehrabadi \& Ali 2009). As our work indicated that at $\mathrm{pH} 6.4$ amylase of mango mealybug showed its maximum activity. It means for proper action of amylases there should be slightly acidic medium.

At $50{ }^{\circ} \mathrm{C}$ temperature, maximum activity of amylase was observed in the mango Mealybug. As it is reported in the literature that lowest and highest temperature ranges that possess the alpha-amylase activity are $25-30{ }^{\circ} \mathrm{C}$ and $100-130{ }^{\circ} \mathrm{C}$ respectively (Chary \& Reddy 1985 ). 
Amylase activity of the $D$. stebbingi was somewhat decreased after remain constant. It may be due to increased in concentration of $\beta$-marcaptoethanol which leads to break Cys-Cys disulphide bridge and inhibit the activity of enzyme.

In the case of metal ions both amylolytic activity was affected by different concentration of the metal ions. In the presence of lead, mercury, sodium, nickel, and cupper the amylase activity was decreased. In the case of potassium and strontium firstly amylase activity was decreased but later on the activity was increased by increase in ion's concentration. While the exposure of calcium stimulated the amylase activity probably due to the reason that amylase is a metalloenzyme and consisting calcium ion as a cofactor so it provides stability to the structure of amylase enzyme. As mentioned in paper that $\mathrm{Ca}^{2+}$ was reported to increase $\alpha$-amylase activity of an alkaliphilic Bacillus sp. ANT-6 (Burhan et al. 2003). In the presence of cobalt ion there were not any effect observed at the amylase activity.

In this preliminary research leaves of Neem, Datura and peel of citrus were used to check the effect on amylase. All the extracts showed the potential inhibitory effect on the amylase activity. Now it requires further investigation on other natural inhibitors by isolation and purification. This may leads to the production of cost effective natural pesticides.

Since these enzymes belong to the digestive system of pest, therefore activity of these enzymes would indicate the feeding behavior of the insect. It has been noted that activity of these enzyme are prone to change in the environment and also affected by the quality of cell sap (xylem fluid). Since it directly feed on the young twigs and tender branches, therefore the activity of these enzymes were tested over the range of abiotic stress such as temperature stress and inorganic salts stress. These stresses are now common part of over mango orchards range, due to abrupt change in the climate and irrigating the mango orchards with poor quality of water (Azevedo et al. 2003). The change in climate and irrigate on the mango orchard with low quality of water, affect the quality of the xylem fluid and this xylem fluid would eventually affect the mango mealy bug population. It also correlated the change in xylem or cell sap due to irrigating water, polluted with heavy metals. Akhtar et al (2000) collected the samples from various orchards from Pakistan of four varieties dosehri, langera, chonsa and substention buldap of macro ( $\mathrm{Na}$, $\mathrm{K}, \mathrm{Ca}$ and $\mathrm{P}$ ) and micro ( $\mathrm{Fe}, \mathrm{Zn}, \mathrm{Cr}, \mathrm{Cd}$ and $\mathrm{Pb}$ ) elements. It was concluded that the high concentration of these metals may be due to irrigation from industrial flowing and sewerage water. Furthermore it was also indicate that concentration of heavy metals in the Pakistan which is very high than normal concentration.

It is noted that the mango crop absorbed substantial amount of heavy metal such as $\mathrm{Cd}, \mathrm{Pb}$ and $\mathrm{Zn}$ in the leaf and twigs due to vehicular intensity, near the orchard. He concluded that amount of heavy metals exceed to the safe limit. Therefore the studies were carried out to check or determine the impact of heavy metals concentration over the key digestive enzymes of the Mealybug.

As result, inhibition effects of different plant extracts and heavy metals are evaluated in this experiment. Plant extracts may be used in the field directly (or as solute with other chemicals) as foliar spray. A lot of work is being done on heavy metals as control of insect pests through bitrophic interactions. Suitable formulation may be formulated in future.

\section{Acknowledgments}

We are very thankful to Muhammad Abu Bakar for his help in chemical analysis and field work.

\section{Conflict of Interests}

The authors declare that they have no conflict of interest throughout the manuscript 


\section{References}

FAO, Production Yearbook (2010) Food and agricultural organization of the United Nations, Rome.

Abraham EG, Nagaragu J, K. DR (1992) Biochemical study of amylase in the silkworm,Bombyx mori L.: comparative analysis in diapausing and nondiapausing strain. Insect Biochemistry and Molecular Bioliology:22:867-873.

Agounkè D, Agricola U, Bokonon-Ganta HA (1988) Rastrococcus invadens Williams (Hemiptera: Pseudococcidae), a serious pest of fruit trees and other plants in West Africa. Bulleton of Entomological Research:78:695-702.

Akhtar M, Anwar M, Pasha MK, Alam GS (2000) Geological Road Log along the Islamabad-Lahore Motorway. Geological Survey of Pakistan.

Azevedo PV, Silva BBd, da Silva VPR (2003) Water requirements of irrigated mango orchards in northeast Brazil. . Agricultural Water Management:58 241-254.

Bokonon-Ganta AH, Groote HD, Neuenschwander P (2002) Socio-economic impact of biological control of mango mealybug in Benin. Agriculture, Ecosystem and Environment:93:367-378.

Bradford MM (1976) A dye binding assay for protein. Analytical Biochemistry:72:248-254.

Burhan A, Nisa U, Gokhan C, Ashabil A, Osman G (2003) Enzymatic properties of novel thermostable, thermophilic, alkaline and chelator resistant amylase from an alkaliphilic Bacillus sp. Process Biochemistry:38:1397-1403.

Chary SJ, Reddy SM (1985) Starch degrading enzymes of two speciesof Fusarium folia. microbiology:30:452.

Dow JA (1984) Extremely high pH in biological systems: a model for carbonate transport. American Journal of physiology:246: 633-635.

Kadziola A, Abe J, Svensson B, Haser R (1993) Crystal and molecular structure of barley a-amylase. Journal of molecular biology 250:195-202.

Khan MA (2001) Control of insect pests of mango. Proc. Inter. Mango workshop 27 Feb.-1 Mar. Direct. Agric-Multan Region, Punjab:224.

Luhanga WW, Gwinner J (1993) Mango mealybug (Rastrococcus iceryoides) on Mangifera indica in Malawi. FAO Plant Protection Bulletin:41:125-126.

Mehrabadi M, Ali RB (2009) Study on Salivary Glands a-amylase In Wheat Bug Eurygaster maura (Hemiptera: Scutelleridae). American Journal of Applied Sciences:6:555-560.

Mendiola-Olaya E, Valencia-Jiménez A, Valdés-Rodríguez S, Délano-Frier J, Blanco-Labra A (2000) Digestive amylase from the larger grain borer, Prostephanus truncatus Horn. Comparative Biochemistry and Physiology - B Biochemistry and Molecular Biology:126:425-433.

MINFAL (2010) Agriculture Statistics of Pakistan. Govt. of Pakistan, Min.of Food, Agri. and Livestock Economic Wing, Islamabad.

Mohammed MA (2004) Purification and characterization of alpha-amylase from the infective juveniles of the nematode Heterorhbditis bacteriophaga. Comparative Biochemistry and Physiology part B:139:1-9.

Narula S (2003) Nip mango mealybug in the bud now Spectrum, Sunday 14, 2003. Tribune (GARDEN LIFE) India.

Oliveira-Neto O, Batista JAN, Rigden DJ, Franco OL, Falcao R, Fragoso RR, Mello LV, Santos RCD, Grossi-de-sa MF (2003) Molecular cloning of amylase from cotton boll weevil, Anthonomus grandis and structural relations to plant inhibitors: An approach to insect resistance. Journal of protein chemistry:22:77-87.

Prasad V, Singh RK (1976) Prevalence and control of mango mealy bug Drosicha stebbingii (Green) in Bihar. Indian Journal of Entomology:38:2144-224.

Rao MS, Reddy NS, Rao GV, Sambasiva Rao KRS (2005) Studies on the extraction and characterization of thermostable a-amylase from pericarp of Borassus indica. African Journal of Biotechnology 4:289-291.

Rehman FU, Aslam M, Taiq MI, Shaheen MA, Amtul JS, Naveed NH, Iram BA (2009) Isolation of cellulolytic activities from (red flour beetle) Tribolium castaneum. African Journal of Biotechnology:8:6710-6715.

Sami AJ, Akhtar MW (1990) Purification and characterization of two native extracellular carboxymethyle cellulose of carboxymethylcellulase of Cellulomonas flavigena. Biochemical Society Transactions:18:651.

Shalom G, Pratten J (2008) Cloning, heterologous gene expression and biochemical characterization of the alpha1,3-glucanase from the filamentous fungus Penicillium purpurogenum. Protein Expression Purification:60:170175. 
Sivakumar D, Jiang Y, Yahia EM (2011) Maintaining mango (Mangifera indica L.) fruit quality during the export chain. Food Research International:44:1254-1263. DOI: http://dx.doi.org/10.1016/j.foodres.2010.11.022.

Tandon PL, Lal B (1978) The mango coccid, Rastrococcus iceryoides Green (Homoptera: Coccidae) and its natural enemies. Current Science:13:46-48.

Tandon PL, Verghese A (1985) World List of Insect, Mite and other Pests of Mango. Technical Document No. 5, IIHR, Banglore:22.

Watanabe H, Tokudat G (2001) Animal cellulases. Cellular and Molecular Life Sciences:58:1167-1178.

Yousuf M (1993) Mango mealybug control with polyethylene bands. Pakistan Entomologist:15:129.

Zeng F, Cohen AC (2000) Comparison of a-amylase and protease activities of a zoophytophagus and two phytophagous Heteroptera. Comparative Biochemistry and Physiology:126:101-106.

Zibaee A, Bandani AR, Kafil M, Ramzi S (2008) Characterization of $\alpha$-amylase in the midgut and the salivary glands of rice striped stem borer, Chilo suppressalis Walker (Lepidoptera: Pyralidae). Journal of Asia-Pacific Entomology:11:201-205. DOI: http://dx.doi.org/10.1016/j.aspen.2008.09.003.

Zoltowska K (2001) Purification and characterization of alpha-amylases from the intestine and muscle of ascaris suum (Nematoda. Acta Biochimica Polonica:48:763-774. 
